\title{
PROBLEMATIKA PEMBELAJARAN BAHASA ARAB DI MADRASAH
}

\author{
Rubini, Hani Zahrani
}

STAI Masjid Syuhada Yogyakarta

$\underline{\text { RubiniHr80@gmail.com, hany08578@gmail.com }}$

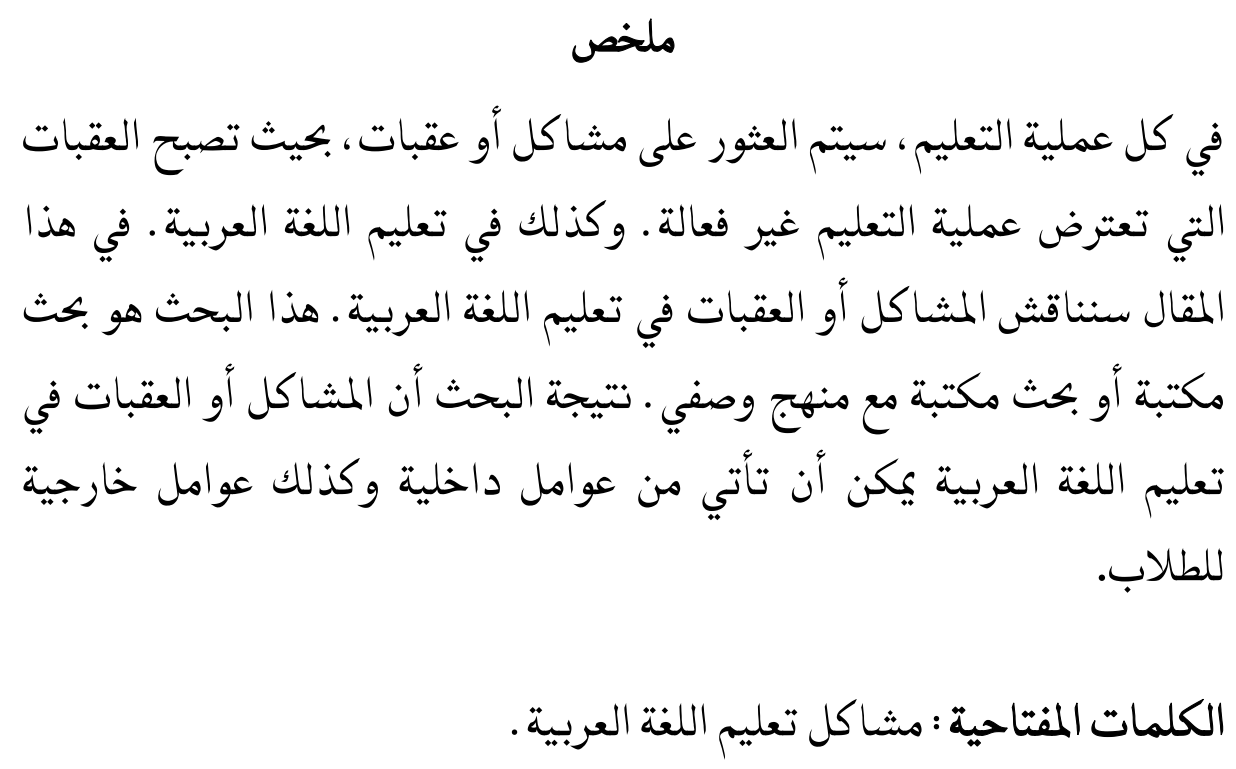

\section{Abstract}

In each learning process, problems or obstacles will be found, so that the obstacles to the learning process become ineffective. Likewise in learning Arabic. In this article, we will discuss the problems or obstacles in learning Arabic. This research is a library research or library research with a descriptive approach. The result of the research is that problems or obstacles in learning Arabic can come from internal factors and also external factors of students.

Keywords: Problems, Arabic Language Learning, Madrasah 


\section{Pendahuluan}

Proses belajar mengajar merupakan sebuah kegiatan penyampaian materi pembelajaran dari seorang tenaga pendidik kepada peserta didik sebagaimana yang dijelaskan dalam UUSPN No. 20 Tahun 2003 yang menyatakan bahwa pembelajaran merupakan proses interaksi antara peserta didik dengan pendidik dan sumber belajar pada suatu lingkungan belajar untuk mencapai tujuan pendidika tertentu. Scunk mengemukakan bahwa pembelajaran merupakan proses interaksi yang melibatkan peserta didik dan konteksnya (guru, bahan dan setting). ${ }^{25}$

Banyak permasalahan yang terjadi di dalam dunia pendidikan, misalnya permasalahan kurikulum, pendidik, sarana dan prasarana, proses pembelajaran, peserta didik, orang tua, masyarakat dan lingkungan pendidikan. Namun hal yang paling dominan dibahas dalam dunia pendidikan adalah guru, karena guru merupakan salah satu faktor utama yang menentukan berhasilnya proses belajar mengajar di dalam kelas, sebagai pendidik guru harus mampu menempatkan dirinya sebagai pengarah dan membina peserta didik ke arah titik maksimal tujuan pendidikan. Guru juga turut andil dalam menunjang proses belajar mengajar, guru lebih dituntut untuk dapat menguasai kelas dengan baik, memiliki kemampuan dalam menyampaikan materi yang

${ }^{25}$ Leli Halimah, Keterampilan Mengajar, (Bandung: Refika Aditama, 2017), hlm. 33 
diajarkannya agar peserta didik mampu memahami materi yang disampaikan dan dapat mengaplikasikannya dalam kehidupan.

Guru sebagai pelaksana pembelajaran tidak hanya dituntut untuk mampu mentransferkan ilmu dan keterampilan saja. Tetapi guru juga bertanggung jawab dalam membentuk kepribadian peserta didik agar dapat menanamkan sikap dan moral yang baik pada anak. Pada dasarnya penanaman sikap dan moral diperoleh melalui pembelajaran agama Islam yang diajarkan di sekolah. Salah satu pelajaran yang banyak menanamkan sikap moral dalam penyampaian pembelajarannya adalah pelajaran bahasa Arab, baik dalam bentuk membiasakan diri para murid untuk menghafal kosa-kata, atau dalam penyampain pesan moral dalam bentuk cerita muthala"eah dalam bahasa Arab.

Pendidikan bahasa Arab adalah salah satu upaya yang dilakukan oleh para pendidik untuk menanamkan kemampuan komunikasi dan juga pemahaman bagi para murid agar nantinya mampu menguasai dan paham ketika membaca kitab atau buku lainnya yang berbahasa Arab. Pendidikan juga merupakan upaya untuk membina manusia agar mampu mewujudkan tujuan penciptaannya. Tujuan dari mata pelajaran bahasa Arab adalah agar peserta didik mampu memahami, meyakini, dan mengamalkan ajaran Islam khususnya yang disampaikan dalam 
bahasa Arab, sehingga menjadi manusia yang beriman dan bertakwa kepada Allah Swt. ${ }^{26}$

Problematika selalu menuntut untuk bisa diselesaikan. Begitu juga dengan problematika pembelajaran bahasa Arab, tidak hanya mengkaji tentang masalah-masalah yang muncul, akan tetapi juga berusaha untuk menemukan solusi dan jalan keluar dari permasalahan tersebut. Munculnya sebuah permasalahan dalam pembelajaran bahasa Arab tidak terlepas dari pendidikan agama yang lebih banyak berorientasi pada aspek kognitif saja, padahal pendidikan yang menanamkan nilai agama dan juga nilai moral yang seharusnya lebih berorientasi secara praktisi, maka tidak heran ketika banyak dijumpai anak yang mendapat nilai bagus dalam mata pelajaran, akan tetapi dalam penerapan dan perilakunya cenderung menyimpang dari norma dan ajaran Islam. Sistem pendidikan dalam penyampaian pelajaran bahasa Arab kurang sistematis dan kurang terpadu untuk anak didik, sehingga anak didik merasa terbeban dan dilema, kemudian juga evaluasi yang dilakukan terhadap pelajaran bahasa Arab cenderung disamakan dengan pelajaran-pelajaran yang lain.

Pada kenyataannya pembelajaran bahasa Arab sekarang ini tidak bisa menciptakan peserta didik yang mampu memahami pelajaran yang disampaikan, sehingga di luar sekolah ia tidak mampu menerapkan apa yang telah dipelajarinya di sekolah, baik

26 Ahmad Susanto, Teori Belajar dan Mengajar di Sekolah, (Jakarta: Prenada Media Group, 2013), hlm. 4. 
itu hafalan kosa-kata dalam bahasa Arab ataupun nilai moral yang disampaikan oleh guru mata pelajaran bahasa Arab tersebut. Hal tersebut adalah dikarenakan anak didik telah terlebih dahulu tidak menyukai pelajaran tersebut, sehingga membuat anak didik merasa tertekan dan pelajaran tersebut menjadi momok baginya.

\section{Bahasa Arab dan Pembelajarannya}

Bahasa Arab merupakan bahasa yang memiliki keistimewaan yang dibandingkan dengan bahasa yang lainnya. Salah satu keistimewaan terbesar yang dimiliki oleh bahasa Arab adalah terpilihnya bahasa tersebut sebagai bahasa Alquran. Karena merupakan bahasa kitab suci dan tuntunan agama umat Islam sedunia, maka tentu saja ia merupakan bahasa yang paling besar signifikansinya bagi ratusan juta muslim sedunia, baik yang berkebangsaan Arab maupun bukan dan serta secara otomatis menjadi media penyampaian pesan-pesan normatif dari Allah Swt. kepada seluruh umat manusia. Sebagaiaman firman Allah swt dalam QS Az-Zukhruf/43: 3 yang artinya:

"Sesungguhnya Kami menjadikan Alquran dalam bahasa Arab supaya kamu memahami(nya)" ${ }^{27}$

Selanjutnya firman Allah swt dalam QS Fussilat/41: 3 yang artinya :

${ }^{27}$ Kementerian Agama RI, Al-Qur"an dan Terjemahanya (Jakarta: Proyek Pengadaan Kitab Suci al-Qur,,an, 2012), hlm, 905. 
"Kitab yang dijelaskan ayat-ayatnya, yakni bacaan dalam bahasa Arab, untuk kaum yang mengetahui" ${ }^{28}$

Ayat-ayat di atas merupakan sebagian dari beberapa ayat yang menegaskan eksistensi bahasa Arab sebagai bahasa wahyu. Apabila dicermati secara mendalam, tergambar bahwa ayat tersebut juga mengindikasikan bahwa bahasa Arab adalah bahasa yang telah terstruktur sedemikian rupa sehingga memungkinkan adanya kemudahan dalam konteks pemahaman sebagai suatu unsur utama dalam berkomunikasi bukan hanya pada skala lokal masyarakat Arab tapi juga dalam dunia internasional. Dalam pengklasifikasian bahasabahasa dunia berdasarkan pendekatan genetis, bahasa Arab termasuk pada rumpun Hamito-Semit atau Afro-Asiatik. ${ }^{29}$

Konsekuensinya, keberadaan bahasa Arab sebagai bagian dari rumpun Hamito-Semit atau bahasa Afro-Asiatik tentunya diwarnai oleh beberapa karakteristik yang melekat pada rumpun bahasa tersebut. Dalam menyikapi hal tersebut, Amrah Kasim menjelaskan beberapa karakteristik yang melekat pada bahasabahasa dalam sub-rumpun Semit, ${ }^{30}$ yaitu:

28 Ibid, Kementerian Agama RI, Al-Qurean dan Terjemahanya, hlm. 881.

29 Safriandi, Pengelompokan Bahasa di Dunia, http://nahulinguistik. wordpress.com / / pengelompokan-bahasa-di-dunia. (03 Maret 2019).

30 Amrah Kasim, Bahasa Arab di Tengah-tengah Bahasa Dunia (Yogyakarta: Penerbit Kota Kembang, 2009), hlm. 21. 
a. Mayoritas kata dasar yang dimiliki bahasa-bahasa dalam sub-rumpun Semit terdiri dari tiga huruf konsonan dan selalu diawali dengan huruf konsonan dalam tulisan.

b. Kata kerja dibentuk berdasarkan waktu terjadinya pekerjaan, sementara kata benda dibentuk dengan sistematika jenis dan jumlah hurufnya.

c. Kata majemuk jarang didapat seperti pada rumpun bahasa „Ariyah kecuali pada hal-hal yang khusus seperti pada bilangan.

d. Derivasi dilakukan dengan menambah huruf atau mengurangi tanpa batasan dengan konsistensi pada makna kata dasar.

e. Kata ganti dan cara menyambungnya dengan kata benda, kata kerja, dan huruf adalah sama.

Menurut Abdul Alim Ibrahim bahasa Arab adalah bahasa orang Arab sekaligus juga merupakan bahasa Islam, ${ }^{31}$ karena bahasa selain bahasa Arab tidak dapat diandalkan untuk memberikan kepastian arti yang tersurat dan tersirat dari makna yang terkandung dalam al-Qur,,an, maka kaedah-kaedah yang diperlukan dalam memahami al-Qur,,an bersendi atas kaedahkaedah bahasa Arab, memahami asas-asasnya, uslub-uslubnya, dan

31 Abdul 'Alim Ibrahim, Al-Muwajjih al-Fanni' li Mudarrisi al-Lugah al'Arabiyyah (Al-Qahirah: Dar al-Ma'arif, 1978), hlm. 48. 
mengetahui rasa-rasanya. ${ }^{32}$ Populernya bahasa Arab seiring dengan perkembangan Islam. Bahasa Arab dan Islam tidak bisa dipisahkan karena adanya al-Quran. AlQur'an merupakan kitab suci Agama Islam, agama terbesar dan paling banyak pengikutnya di dunia ini menggunakan bahasa Arab seperti ditegaskan dalam firman Allah swt dalam QS Yusuf/12: 2;

"Sesungguhnya Kami menurunkannya berupa Alquran dengan berbahasa Arab, agar kamu memahaminya". 33

Semua pengamat baik orang Barat maupun orang muslim Arab menganggap bahasa Arab sebagai bahasa yang memiliki standar ketinggian dan keelokan linguistik yang tertinggi, yang tiada taranya. Sejak bahasa Arab yang tertuang dalam Alquran didengungkan hingga kini. Hal ini tentu saja berdampak pada munculnya superioritas sastra dan filsafat bahkan pada sains seperti ilmu matematika, kedokteran, ilmu bumi, dan tata bahasa Arab sendiri pada masa-masa kejayaan Islam setelahnya.

Ali al-Najjar mengungkapakan bahasa Arab merupakan bahasa yang terluas dan terkaya kandungannya, deskripsi dan pemaparannya sangat mendetail dan dalam. Sementara Abdul Hamid bin Yahya dalam al Hasyimiy berkata: Aku mendengar Abu Syu'bah berkata: "Pelajarilah bahasa Arab karena bahasa Arab itu

${ }^{32}$ Hasbi Ash-Shiddieqy, Falsafah Hukum Islam (Jakarta:Bulan Bintang, 1975), hlm. 57.

33 Ibid, Kementerian Agama RI, Al-Qur'an dan Terjemahnya..., hlm.41. 
akan menambah ketajaman daya nalar."34 Kedudukan istimewa yang dimiliki oleh bahasa Arab di antara bahasabahasa lain di dunia adalah karena ia berfungsi sebagai bahasa Alquran dan Hadis serta kitab-kitab lainnya. Akkawi menulis bahwa Amir al$\mathrm{Mu}$,minin Umar bin al-Khattab r.a berkata: “Hendaklah kamu sekalian tamak (keranjingan) mempelajari bahasa Arab karena bahasa Arab merupakan bagian dari agamamu. ${ }^{35}$

Di sinilah pengetahuan tentang bahasa Arab memegang peranan yang sangat penting untuk lebih memahahami ajaranajaran agama guna ditransfer ke benak masyarakat awam, ke benak murid-murid yang cukup kritis. ${ }^{36}$ Bahasa Arab juga sering disebut mempunyai kepustakaan besar di semua bidang ilmu pengetahuan, ilmu pengetahuan filsafat dan matematika Yunani sampai ke barat melalui terjemahan dan tafsiran orang-orang Arab. Bahasa Arab juga pernah menjadi bahasa internasional dalam sejarah, sampai masa sekarang bahasa Arab masih tetap bertahan keinternasionalannya sejajar dengan kedua bahasa internasional modern yakni bahasa inggris dan bahasa perancis, ribuan karya monumental semisal al-qanun fi al-t'ib (aturan dalam kedokteran), al-madkhal ila 'ilm al-nujum (observasi pergerakan bintang), maqas'id

34 Ahmad al-Hasyimi, Al-Qawa'id al-Asasiyyah li-Lugah al-'Arabiyyah (Bairut: Dar al Kutub al-„Ilmiyyah,1354 H), hlm. 97.

${ }_{35}$ Mahmud Jad Akawi, Al-Muhasah al-Yaumiyyah bi al-Lugah al 'Arabiyah (Beirut: Dar al-jail,1987), hlm. 45.

36 Azhar Arsyad, Bahasa Arab dan Metode Pengajarannya: Beberapa Pokok Pikiran (Yogyakarta:Pustaka Pelajar, 2004), hlm. 6-7. 
al-falasifah (tujuan para filosof), serta segudang literatur lain yang dijadikan referensi di banyak universitas di Eropa. ${ }^{37}$

Di Amerika, hampir tidak ada suatu perguruan tinggi yang tidak menjadikan bahasa Arab sebagai mata kuliah, termasuk perguruan tinggi Katholik atau Kristen. Sebagai contoh Harvard University, sebuah perguruan tinggi swasta paling terpandang di dunia yang didirikan oleh para tokoh agama protestan, dan Georgetown University, sebuah universitas swasta Katholik, keduanya mempunyai pusat studi Arab yang kurang lebih merupakan Center for Contemporary Arab Studies. ${ }^{38}$

Selain di Amerika tepatnya di Afrika, bahasa Arab ini dituturkan dan menjadi bahasa pertama di negara-negara semacam Mauritania, Maroko, Aljazair, Libya, Mesir dan Sudan. Di semenanjung Arabia, bahasa ini merupakan bahasa resmi di Oman, Yaman, Bahrain, Kuwait, Saudi, Qatar, Emirat Arab dan jauh ke utara, Jordan, Irak, Syiria, Libanon, dan Palestina. Menurut Wise, bahasa Arab juga merupakan bahasa orang-orang India Utara, sebagian orang Turki, Iran, Portugal, dan Spanyol.

Keberadaan bahasa Arab sebagai bahasa internasional adalah sebuah realitas empris yang tidak terbantahkan. Pada tahun 1973, bahasa Arab mendapatkan posisi yang sangat istimewa di antara bahasa-bahasa internasional yang telah mendapatkan posisi

37 Asep Hermawan, Metodologi Pembelajaran Bahasa Arab (Bandung:PT. Remaja Rosdakarya, 2013), hlm. 83.

${ }^{38}$ Hilary Wise, Arabic at Glanc (New York: Barron,,s Educational Series Inc, 1987), hlm. 87. 
yang sama sebelumnya sebagai bahasa resmi yang dipergunakan dalam forum Perserikatan Bangsa-Bangsa (PBB). Adanya pengakuan atas bahasa Arab sebagai salah satu bahasa resmi yang dipergunakan dalam forum Perserikatan Bangsa-Bangsa (PBB) mendorong bahasa Arab sebagai salah satu alat komunikasi resmi dalam interaksi sosial umat manusia di berbagai belahan dunia baik itu dalam bentuk komunikasi aktif ataupun komunikasi pasif.

Eksistensi bahasa Arab sebagai bahasa internasional bukanlah suatu hal yang sifatnya kebetulan semata. Dalam menyikapi hal tersebut, Azhar Arsyad mengemukakan bahwa karakter bahasa Arab sebagai bahasa internasional sudah terlihat sejak kebangkitan sastra Arab pasca lahirnya Islam yang mencakup beberapa bangsa yang berbeda-beda. Semua bangsa yang berbedabeda tersebut menyatu dalam menampilkan diri sebagai bangsa-bangsa yang berbudaya dengan identitas Arab seperti Pakistan, Afghanistan, dan semacamnya. Ciri lainnya yang melekat pada bahasa Arab sebagai bahasa internasional adalah banyaknya lafal bahasa Arab yang kemudian terserap masuk ke dalam berbagai bahasa-bahasa terkemuka di dunia. ${ }^{39}$

Tidak mengherankan kemudian apabila pembelajaran bahasa di berbagai belahan dunia mengalami kemajuan yang cukup mengembirakan baik sebagai bahasa kedua ataupun sebagai bahasa asing yang tentunya dilandasai dengan berbagai orientasi

${ }^{39}$ Ibid, Azhar Arsyad, Bahasa Arab dan Metode Pengajarannya: Beberapa Pokok Pikiran..., hlm. 14-15. 
yang cukup bervariasi. Dalam kaitannya dengan orientasi pembelajaran bahasa Arab di berbagai belahan dunia, Asep Hermawan merinci sebagai berikut:

1 Orientasi Religius Orientasi ini mengindikasikan bahwa belajar bahasa Arab untuk tujun memahami dan memahamkan ajaran Islam (fahm al-maqru'). Orientasi ini dapa berupa belajar keterampilan pasif (mendengar dan membaca), dan dapat pula mempelajari keterampilan aktif (berbicara dan menulis)

2 Orientasi Akademis Orientasi ini mengindikasikan bahwa pembelajaran bahasa Arab diorientasikan pada tujuan-tujuan akademik dimana bahasa Arab memainkan peran sesuai dengan fungsinya baik sebagai alat untuk mengkaji ilmu-ilmu yang lain ataupun sebagai obyek studi yang berdiri sendiri dengan segala cabang-cabangnya. Orientasi ini biasanya identik dengan pembelajaran bahasa Arab pada Jurusan/Program Studi Pendidikan Bahasa Arab ataupun Bahasa dan Sastra Arab.

3 Orientasi Profesional, Praktis dan Pragmatis Orientasi ini mengindikasikan bahwa pembelajaran bahasa Arab diorientasikan pada kepentingan profesi, praktis atau pragmatis seperti pembelajaran bahasa Arab bagi mereka yang ingin bekerja di negaranegara Arab sebagai Tenaga Kerja Indonesia (TKI). Tenaga Kerja Wanita (TKW), diplomat, turis, misi perdagangan, dan semacamnya. 
4 Orientasi Ideologis dan Ekonomis Orientasi ini mengindikasikan bahwa pembelajaran bahasa Arab diorientasikan pada pemahaman dan penggunaan bahasa Arab sebagai media untuk kepentingan orientalisme, kapitalisme, imperialisme, dan semacamnya. Salah satu contoh konkrit dari pembelajaran bahasa Arab dengan orientasi seperti ini adalah bagaimana tentara Amerika Serikat diasramakan untuk belajar bahasa Arab sebelum dikirim bertugas di negara-negara Arab. ${ }^{40}$

Dapat diketahui dan dipahami bahwa pentingnya bahasa Arab yaitu khususnya bagi umat Islam baik yang berdomisili di Arab maupun di negara lainnya. Akan tetapi yang menjadi permasalahan adalah dalam pembelajarannya bagi orang-orang asing (non-Arab), seperti halnya pembelajaran bahasa Arab di negara Indonesia yang mana mayoritas penduduknya adalah umat Islam. Telah diketahui, bahwa bahasa Arab adalah salah satu bahasa asing yang diajarkan di sebagian sekolah-sekolah di Indonesia, baik itu sekolahan di kota maupun di desa-desa, dan kebanyakan, bahasa Arab diajarkan di madrasah-madrasah dan pondok-pondok pesantren yang tersebar diseluruh wilayah Indonesia, mulai dari sekolah dasar sampai Perguruan Tinggi. Di Indonesia terdapat dua tipe sekolah Islam yaitu pesantren dan Madrsah. Bahkan beberapa orang tua lebih suka mengirim anak

${ }^{40} \mathrm{Ibid}$, Asep Hermawan, Metodologi Pembelajaran Bahasa Arab...., hlm. 89-90. 
mereka ke pesantren dan dimana santri laki-laki dan wanita di tempatkan pada kelas yang berbeda dan lingkungan belajar, dan biasanya lembaga pendidikan tersebut berdomisli di daerah pedesaan dengan bimbingan kiyai. Di pesantren peserta didik dituntut untuk memahami Alquran, Bahasa Arab dan Hukum Islam. ${ }^{41}$

Di samping itu tujuan pengajaran bahasa Arab adalah untuk memperkenalkan berbagai bentuk ilmu bahasa kepada peserta didik yang dapat membantu memperoleh kemahiran berbahasa, dengan menggunakan berbagai bentuk dan ragam bahasa untuk berkomunikasi, baik dalam bentuk lisan maupun tulisan, untuk tercapainya tujuan tersebut para pengajar atau ahli bahasa, pembuat kurikulum atau program pembelajaran harus memikirkan materi atau bahan yang sesuai dengan tingkat kemampuan peserta didik serta mencari metode atau teknik pengajaran ilmu bahasa dan kemahiran berbahasa Arab, dan melatih peserta didik dalam kehidupan sehari-hari, baik kemahiran membaca, menulis dan berbicara. Kemahiran dasar yang harus dimiliki dalam memahami bahasa Arab dalam menguasai ilmu bahasa dan kemahiran berbahasa Arab beserta kaidahnya-kaidahnya, menghafal atau menguasai kosa-kata (mufradat) beserta artinya. Kaidah-kaidah bahasa Arab dipelajari dalam mata kuliah ilmu nahwu dan ilmu sharaf.

41 Muhammad Wayong, University Management (A Gender Perspective), (Yogyakarta: Penerbit Cakrawala, 2010), hlm. 150. 
Sedangkan mufradat dapat dikuasai melalui mata pelajaran mutala'ah dan muhadasah, karena kedua pelajaran tersebut sangat bergantung pada penguasaan kosa-kata. Dalam menguasai kaidahkaidah bahasa Arab memerlukan kepada penguasaan nahwu dan sharaf. Nahwu digunakan untuk mempelajari struktur kalimat dan perubahan baris akhir. Sedangkan sharaf digunakan untuk mempelajari dasar kata beserta perubahannya. Selanjutnya untuk memperoleh kemahiran menyimak dan membaca perlu mempelajari ilmu mutala'ah. Untuk memperoleh kemahiran menulis atau mengarang perlu mempelajari ilmu insya' dan untuk memperoleh kemahiran berbicara perlu mempelajari ilmu muhadasah.

Pada dasarnya, pembelajaran bahasa asing tidaklah mudah, akan tetapi seringkali terdapat kesulitan-kesulitan yang dihadapi oleh guru dan murid. Sebagian dari kesulitan-kesulitan itu adalah seperti yang dikatakan oleh Muhammad Atiyah al-Abrasyi, bahwa dalam pembelajaran bahasa asing, sebagian besar peserta didik masih menghafalkan kalimat-kalimat (vocabularies) akan tetapi tidak mampu memahami maknanya. ${ }^{22}$ Seharusnya guru tidak boleh memaksa dan membebani peserta didik dengan hafalan kalimat yang tidak diketahui maknanya, karena hal tersebut bukanlah cara yang baik untuk mempelajari bahasa asing. Berdasarkan hal tersebut, tentunya kita membutuhkan strategi

42 Radliah Zainudin, Pembelajaran Bahasa Arab (Jakarta: Pustaka Rihlah Group, 2005), hlm. 54. 
yang jitu dalam mengatasi kesulitan-kesulitan dalam pembelajaran bahasa asing, khususnya bahasa Arab.

Perlu diperhatikan dalam pembelajaran bahasa Arab dengan tujuan untuk menghilangkan kesan bahwa bahasa Arab itu sulit dan memusingkan maka guru harus mengerti tingkatan peserta didik yang sedang diajar, agar bisa memberikan materi sesuai dengan tingkat peserta didik pada saat itu.

Pemberian materi yang sesuai akan mempercepat pemahaman peserta didik, jangan sampai pada saat peserta didik masih pada tahap pemula (mubtadi in) dalam mempelajari bahasa Arab, guru memberikan materi yang terlalu sulit seperti mengarang, bercerita dalam bahasa Arab tentu itu akan membuat peserta didik yang baru belajar bahasa Arab akan merasa sangat kesulitan, sehingga timbullah kepahaman pada diri peserta didik bahwa bahasa Arab itu sulit, begitu juga sebaliknya pemberian materi yang terlalu ringan kepada peserta didik yang sudah pada tingkat mahir (mutaqaddimi'n) akan membuat peserta didik merasa cepat bosan karena meteri itu sudah dia kuasai, pengenalan awal terhadap tingkatan peserta didik akan sangat membantu seorang guru dalam memberikan sebuah materi yang cocok, hal ini sesuai dengan yang dikatakan Yusuf bahwa pembelajaran bahasa Arab 
perlu dipersiapkan materi dengan baik yang disesuaikan dengan taraf perkembangan anak didik. ${ }^{43}$

Maman Abdurrohman dalam bukunya Pengembangan Ajar Bahasa Arab Terpadu menyampaikan beberapa tips dan cara untuk menghindari kesan bahwa belajar bahasa Arab itu sulit maka yang harus dilaksanakan adalah sebagai berikut:

1. Mengajarkan bahasa Arab percakapan dengan kata-kata yang sederhana dan mudah dimengerti oleh peserta didik.

2. Menggunakan alat peraga atau alat bantu, hal ini penting agar pembelajaran menarik, bergairah, dan mudah difahami.

3. Mengaktifkan seluruh panca indra anak didik, lidah dilatih dengan percakapan, mata dilatih dengan membaca, dan tangan dilatih dengan menulis dan mengarang. ${ }^{44}$

Dalam Pembelajaran bahasa Arab telah diketahui bahwa tingkatan pembelajaran bahasa Arab terdiri atas:

1. Mubtadi in (Pemula) Mubtadi in (pemula) adalah tingkatan yang paling awal dalam pembelajaran bahasa Arab, dan biasanya materi yang paling cocok untuk tingkatan ini adalah: menghafalkan mufrodat, percakapan yang sederhana, dan mengarang terarah (al-insya'al-muwajjah) ini biasanya digunakan

43 Yusuf, Tasmiim Manhaj li Ta"limi al Lughah al-Arabiyah (Kairo: Da>r al-Saqofah, 1997), hlm. 193.

44 Maman Abdurohman, Pengembangan Ajar Bahasa Arab Terpadu (Jakarta: Depdiknas, 2009), hlm. 20 
pada level bawah karena ia mencakup kegiatan mengarang yang dimulai dari merangkai huruf, kemudian kata dan kalimat. ${ }^{45}$

2. Mutawasit'in (Menengah) Peserta didik pada tingkatan ini berarti dia sudah mendapatkan beberapa materi tentang bahasa Arab, dan tugas seorang guru pada saat itu adalah memberi penguatan terhadap materi-materi yang sudah didapatkan oleh peserta didik, sehingga bisa mahir dalam materi tersebut.

3. Mutaqaddimi'n (Mahir) Pada tingkatan ini peserta didik sudah mulai mahir terhadap materi-materi berbahasa Arab dan materi yang sesuai bagi peserta didik yang sudah pada tingkatan ini adalah mengarang bebas (al-insya' al-hurr) ini biasanya digunakan pada level tingkat tinggi karena di tingkatan ini keterampilan, kreatifitas dari seorang penulis sangat diandalkan. ${ }^{46}$

\section{Problematika atau Kendala-kendala dalam Pembelajaran Bahasa} Arab di Madrasah

Membahas mengenai kendala-kendala pembelajaran, banyak ahli yang menyebutkan bahwa kendala-kendala yang dihadapi dalam suatu proses pembelajaran itu sama dengan masalah-masalah pembelajaran. Menurut Kamus Besar Bahasa Indonesia, kendala merupakan halangan, rintangan, keadaan yang

45 Radhiah Zainudin , Pembelajaran Bahasa Arab (Yogyakarta: Pustaka Rihlah Group, 2005), hlm. 81.

${ }^{46}$ M. Ainin dkk, Evaluasi Dalam Pembelajaran Bahasa Arab (Bandung: Myskat: 2006), hlm. 144. 
membatasi suatu kegiatan baik formal maupun non formal. ${ }^{47}$ Sedangkan pengertian masalah merupakan ketidaksesuaian antara harapan dengan kenyataan. Ada yang melihat sebagai tidak terpenuhinya kebutuhan seseorang dan adapula yang mengartikannya sebagai suatu hal yang tidak mengenakan.

Menurut Herman Yanuar, kendala pembelajaran merupakan halangan atau kesulitan yang dihadapi saat berlangsung kegiatan proses belajar mengajar. Sedangkan kesalahan mempunyai arti kekeliruan, kekhilafan yang dilakukan baik sengaja maupun tidak sengaja. ${ }^{48}$ Pada suatu proses pembelajaran, kendala atau masalah bisa timbul diakibatkan beberapa faktor, baik faktor internal peserta didik, maupun dari faktor eksternal. Sumadi Suryabrata dalam bukunya Psikologi Pendidikan, menyatakan bahwa faktor yang mempengaruhi proses dan prestasi belajar adalah faktor dari dalam diri peserta didik dan faktor dari luar diri peserta didik. Faktor dari dalam diri peserta didik meliputi kondisi psikologis dan fisiologis, sedangkan faktor dari luar meliputi lingkungan keluarga dan lingkungan masyarakat serta kelengkapan berbagai sarana dan prasarana dalam belajar. ${ }^{49}$ hlm. 534

${ }^{47}$ Kamus Besar Bahasa Indonesia Edisi Ketiga (Jakarta: Balai Pustaka, 2011),

48 Yanuar Herman, Problematika Pendidikan (Bandung : Sinar Baru, 2007), hlm. 34 . hlm. 27.

49 Suryabrata Sumadi, Psikologi Pendidikan (Jakarta : Rajawali, 1987), 
Selanjutnya dikemukakan pula oleh Bedjo Peserta didiknto, bahwa keberadaan faktor-faktor yang mempengaruhi proses belajar dan prestasi belajar peserta didik terdapat hubungan yang saling terkait. Bakat yang ada dalam diri peserta didik misalnya agar dapat berkembang baik, maka perlu ada dorongan dari keluarga dan masyarakat. Sebaliknya, lingkungan yang kurang mendukung dapat menghambat perkembangan peserta didik itu sendiri. Secara ringkas, faktor-faktor penghambat yang menjadi kendala dalam pembelajaran bahasa Arab di Madrasah Tsanawiyah terbagi dalam dua faktor, yaitu faktor internal peserta didik terutama peserta didik lulusan SD murni dan faktor eksternal peserta didik. Di antara faktor-faktor internal peserta didik sebagai penyebab yang menjadi kendala dalam pembelajaran bahasa Arab adalah:

1. Latar Belakang Pendidikan Peserta didik. Latar belakang pendidikan merupakan modal dasar bagi peserta didik dalam mempelajari bahasa Arab di tingkat Madrasah Tsanawiyah. Hal ini juga menentukan perbedaan dalam proses pembelajaran bahasa Arab antara peserta didik yang lulusan MI apalagi yang sekalian belajar di pondok pesantren dengan peserta didik yang lulusan SD yang sama sekali belum pernah belajar bahasa Arab.

2. Faktor bakat peserta didik. Bakat biasanya diartikan sebagai kemampuan bawaan yang merupakan potensi (potential ability) yang masih perlu dikembangkan atau dilatih agar dapat 
terwujud. Bakat merupakan kemampuan alamiah untuk memperoleh pengetahuan atau keterampilan, yang relatif bisa bersifat umum (misalnya, bakat intelektual umum) atau khusus (bakat akademis khusus). ${ }^{50}$ Bakat peserta didik menjadi kendala dalam pembelajaran bahasa Arab, karena terdapat banyak peserta didik yang masih belum menyadari akan bakat yang dimilikinya, sehingga mereka kebingungan untuk mengembangkan bakat tersebut.

3. Minat peserta didik. Minat merupakan Kecenderungan yang tetap untuk memperhatikan dan mengenang beberapa kegiatan. Kegiatan yang diminati seseorang, diperhatikan terus menerus yang disertai rasa senang tanpa adanya batasan waktu. ${ }^{51}$ Minat peserta didik lulusan SD dalam mempelajari bahasa Arab di Madrasah Tsanawiyah khususnya di Madrasah Tsanawiyah di Kota Langsa ini menjadi masalah, karena banyak peserta didik yang sudah menjustifikasi bahwa dirinya tidak mampu dan tidak akan bisa dalam memahami bahasa Arab.

4. Kemauan atau motivasi peserta didik. Faktor paling fundamental untuk memperoleh hasil yang baik terhadap segala sesuatu yang diinginkan oleh seseorang adalah kemauan. Keamauan ini akan jauh lebih baik jika muncul dari kesadaran

50 Alex Sobur, Psikologi Umum (Bandung : Pustaka Setia: 2003), hlm. 18

51 Slamet, Belajar dan Faktor-Faktor yang Mempengaruhinya (Jakarta: PT Rineka Cipta, 2005), hlm. 57. 
pada diri seseorang tanpa adanya paksaan dari luar diri seseorang.

Adapun faktor-faktor eksternal yang menjadi kendala dalam proses pembelajaran bahasa Arab di Madrasah Tsanawiyah diantaranya adalah :

1. Buku-buku paket bahasa Arab terkesan sulit dan padat dengan materi. Serta isi buku terkadang tidak relevan dengan realitas peserta didik yang ada, sehingga hal ini menyebabkan peserta didik belajar bahasa Arab kurang termotivasi.

2. Di sebagian sekolah, tenaga pengajarnya bukan dari jurusan bahasa Arab (tidak memiliki keterampilan bahasa Arab yang memadai). Ada guru yang mahir keterampilan bahasanya, tetapi keterampilan mengelola kelasnya kurang (bukan guru profesional) dan kalau ada guru yang profesionalnya tinggi, tidak diimbangi dengan kompetensi kemahiran berbahasa yang baik. Ini juga akan menentukan hasil pembelajaran bahasa Arab. Alangkah baiknya, jika guru memiliki keterampilan bahasa (istima „, kalam, qiraah, dan kitabah) dan memiliki kompetensi dalam mangatur kelas dengan piawai memilih metode, teknik, media, materi, dan mengetahui kondisi, motivasi, dan kemampuan peserta didik-peserta didiknya, sehingga dapat benar-benar dapat menyajikan pembelajaran bahasa Arab yang menyenangkan dan peserta didik dapat meningkatkan kompetensi bahasanya. 
3. Waktu dan jam pembelajaran di sekolah-sekolah yang menganut kurikulum Kementerian Agama dan Kementerian Pendidikan dan Kebudayaan hanya 2 jam pelajaran dalam satu minggu. Waktu yang terbatas membuat pembelajaran bahasa Arab semakin lama tercapai. Karena itu perlu ada jam tambahan (ekstra) untuk menambah jam belajar bahasa Arab.

4. Kurangnya faktor pendukung bagi perolehan bahasa Arab bagi peserta didik, artinya peserta didik jarang mendengarkan ungkapan-ungkapan Arab, berbicara Arab, membaca teks Arab, dan menulis kalimat-kalimat Arabiyah. Intinya faktor pendukung pembelajaran bahasa Arab adalah adanya lingkungan bahasa Arab. Jika ada lingkungan bahasa Arab, maka bahasa Arab dengan sendirinya terserap oleh peserta didik-peserta didik untuk kemudian diterapkan dalam komunikasi sehari-hari.

5. Ditambah dengan faktor Lingkungan, baik lingkungan keluarga, masyarakat, maupun lingkungan pendidikan.

Tantangan pembelajaran bahasa Arab lainnya yang tidak boleh dipandang remeh adalah rendahnya minat dan motivasi belajar peserta didik untuk belajar bahasa Arab. Suasana pembelajaran yang lesu, kaku, serta kurang berkesan menjadi pemandangan umum dari realitas pembelajaran bahasa Arab hampir di setiap level pendidikan, mulai dari level pendidikan 
dasar sampai level perguruan tinggi, yang mewajibkan pembelajaran bahasa Arab di dalamnya. Hasilnya, proses pembelajaran bahasa Arab yang seharusnya berlangsung secara aktif, inovatif, kreatif, efektif, dan menyenangkan berubah menjadi saat-saat yang membosankan dan penuh beban bagi para peserta didik, pengajar yang mengajarkan bahasa Arab kemudian diberi berbagai label negatif seperti pengajar yang judes bergamis lengkap dengan pecinya tapi jarang senyum, pengajar yang vokal bicara teoretis tapi miskin aksi pada tataran praktis, dan semacamnya. Bahkan saat lonceng atau bel tanda waktu istirahat atau pulang berbunyi, senyum riang tergambar dari wajah para peserta didik seolah-olah mereka baru saja terbebas dari beban yang memasung kebebasan dan keceriaan mereka. ${ }^{52}$

Dalam menyikapi fenomena tersebut, Ahmad Syalabi menggambarkan bahwa ada kesan bahwa bahasa Arab menduduki posisi satu tingkat di bawah bahasa Inggris khususnya pada tataran pencapaian tujuan pembelajaran. Bahasa Arab yang dipelajari dalam waktu yang cukup lama dalam berbagai level pendidikan terkadang belum mampu menunjukkan kompetensi yang diharapkan dibandingkan dengan pembelajaran bahasa Inggris yang cenderung menghabiskan waktu yang relatif lebih singkat tapi dapat menunjukkan pencapaian kompetensi yang cukup

52 Muhammad Rusydi, Pembelajaran Bahasa Arab Komunikatif: Suatu Interpretasi Psikolinguistik atas Implementasinya pada Program PIKIH UIN Alauddin Makassar (Tesis: PPS UIN Alauddin Makassar, 2010), hlm. 3 
signifikan. ${ }^{53}$ Realitas ini juga dikuatkan dengan sebuah survey yang pernah dilakukan pada dua Madrasah Aliyah Negeri di Jakarta dengan melibatkan sekitar 170 peserta didik yang ada pada dua sekolah tersebut dan hasil survey menunjukkan bahwa peserta didik lebih senang dan termotivasi belajar bahasa Inggris daripada belajar bahasa Arab.

\section{Kesimpulan}

Problematika adalah kendala atau permasalahan yang masih belum dapat dipecahkan sehingga untuk mencapai suatu tujuan menjadi terhambat dan tidak maksimal. faktor internal peserta didik dan faktor eksternal peserta didik sebagai penyebab yang menjadi kendala dalam pembelajaran bahasa Arab.

1. Faktor internal peserta didik meliputi:
a. Latar Belakang Pendidikan peserta didik.
b. Faktor bakat peserta didik.
c. Minat peserta didik.
d. Kemauan atau motivasi peserta didik.

2. Faktor eksternal peserta didik, yaitu:

a. Buku-buku paket bahasa Arab terkesan sulit dan padat dengan materi.

53 Ibid, Muhammad Rusydi, Pembelajaran Bahasa Arab Komunikatif..., hlm. 5. 
Rubini, Hani Zahrani : Problematika Pembelajaran Bahasa Arab di Madrasah

b. Di sebagian sekolah, tenaga pengajarnya bukan dari jurusan bahasa Arab

c. Waktu dan jam pembelajaran di sekolah-sekolah yang kurang

d. Kurangnya faktor pendukung bagi perolehan bahasa Arab bagi peserta didik

e. Ditambah dengan faktor Lingkungan, baik lingkungan keluarga, masyarakat, maupun lingkungan pendidikan. 


\section{Daftar Pustaka}

Abdul Alim Ibrahim, Al-Muwajjih al-Fanni li Mudarrisi al-Lugah al Arabiyyah, Al-Qahirah: Dar al-Ma'arif, 1987

Ahmad al-Hasyimi, Al-Qawa'id al-Asasiyyah li-Lugah al'Arabiyyah, Bairut: Dar al Kutub al-'Ilmiyyah, 1354

Ahmad Susanto, Teori Belajar dan Mengajar di Sekolah. Jakarta: Prenad Media Group, 2013

Alex Sobur, Psikologi Umum. Bandung : Pustaka Setia, 2003

Amrah Kasim, Bahasa Arab di Tengah-tengah Bahasa Dunia. Yogyakarta: Penerbit Kota Kembang, 2009

Asep Hermawan, Metodologi Pembelajaran Bahasa Arab. Bandung:PT, Remaja Rosdakarya, 2013

Azhar Arsyad, Bahasa Arab dan Metode Pengajarannya: Beberapa Pokok Pikiran, Yogyakarta:Pustaka Pelajar, 2004

Hasbi Ash-Shiddieqy, Falsafah Hukum Islam. Jakarta:Bulan Bintang, 1975

Hilary Wise, Arabic at Glanc. New York: Barrons Educational Series Inc, 1987

Kemendikbud, Kamus Besar Bahasa Indonesia Edisi Ketiga, Jakarta: Balai Pustaka, 2011

Kementerian Agama RI, Al-Qur"ean dan Terjemahanya, Jakarta: Proyek Pengadaan Kitab Suci al-Qur'an, 2012

Leli Halimah, Keterampilan Mengajar, Bandung: Refika Aditama, 2017

Mahmud Jad Akawi, Al-Muhasah al-Yaumiyyah bi al-Lugah al 'Arabiyah, Beirut: Dar al-jail, 1987 
Maman Abdurohman, Pengembangan Ajar Bahasa Arab Terpadu, Jakarta: Depdiknas, 2009

M. Ainin dkk, Evaluasi Dalam Pembelajaran Bahasa Arab, Bandung: Myskat, 2006

Muhammad Rusydi, Pembelajaran Bahasa Arab Komunikatif: Suatu Interpretasi Psikolinguistik atas Implementasinya pada Program PIKIH UIN, Alauddin Makassar, Tesis: PPS UIN Alauddin Makassar, 2010

Muhammad Wayong, University Management (A Gender Perspective), Yogyakarta: Penerbit Cakrawala, 2010

Radliah Zainudin, Pembelajaran Bahasa Arab, Jakarta: Pustaka Rihlah, Group, 2005

Safriandi, Pengelompokan Bahasa di Dunia, http://nahulinguistik. wordpress.com// pengelompokan-bahasa-di-dunia,(03 Maret 2019).

Slamet, Belajar dan Faktor-Faktor yang Mempengaruhinya, Jakarta: PT Rineka Cipta, 2005

Suryabrata Sumadi, Psikologi Pendidikan, Jakarta : Rajawali, 1987

Yanuar Herman, Problematika Pendidikan, Bandung : Sinar Baru, 2007

Yusuf, Tasmim, Manhaj li Ta'limi al Lughah al-Arabiyah, Kairo: Dar as Saqofah, 1997 